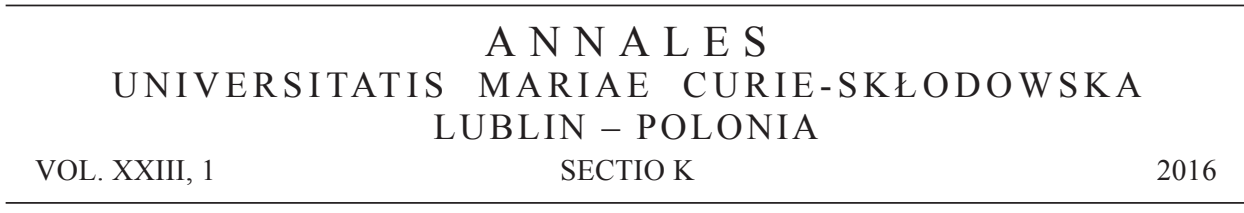

Institute of Political Science and International Affairs, Catholic University of Lublin, Poland

\title{
The Ukraine Crisis and European Union's Eastern Partnership Revisited ${ }^{1}$
}

\begin{abstract}
The objective of the present paper is an attempt at viewing the European Neighbourhood Policy, and especially the Eastern Partnership, from the EU's standpoint and from the international perspective as well. The situation in the EU's eastern neighbourhood (Russia-Ukraine war) drives EU decision-makers to focus merely on stabilisation and de facto stagnation. The decision-makers are not willing to undertake decisive actions towards a change in relations with the countries of Eastern Europe and the South Caucasus. The paper will also consider the following research questions: Will the lack of clear EU membership perspective (even a remote one) for countries such as Ukraine, Moldova, lead to the opportunity for a change of their situation to be forfeit? Will Russia-Ukraine conflict (and Russia-the West conflict in a broad sense) result in the EU being pushed out of the region and enable Russia to reintegrate the post-Soviet space? Was the recent 2015 Eastern Partnership Summit in Riga the beginning of the end of the policy? The paper does not attempt a comprehensive discussion of the issue, but constitutes an outline of particular problems which the EU and Eastern Partnership are faced with.
\end{abstract}

Key words: European Neighbourhood Policy, Eastern Partnership, Eastern Europe, Russia, Ukraine, Russia-Ukraine conflict

1 Article prepared in the framework of the National Science Centre grant titled "European Neighbourhood Policy: (multi-level) governance, the reform process and the prospect of enhanced cooperation in the region", OPUS/HS5, No. 2013/09/B/HS5/04534. 


\section{INTRODUCTION}

The objective of the present paper is an attempt at viewing the European Neighbourhood Policy (abbrev. ENP), and especially the Eastern Partnership, from the EU's standpoint and from the international perspective as well. The situation in the EU's eastern neighbourhood (Russia-Ukraine war) drives EU decision-makers to focus merely on stabilisation and de facto stagnation. The decision-makers are not willing to undertake decisive actions towards a change in relations with the countries of Eastern Europe and the South Caucasus. The paper will also consider the following research questions: Will the lack of clear EU membership perspective (even a remote one) for countries such as Ukraine, Moldova, lead to the opportunity for a change of their situation to be forfeit? Will Russia-Ukraine conflict (and Russia-the West conflict in a broad sense) result in the EU being pushed out of the region and enable Russia to reintegrate the post-Soviet space? Was the recent 2015 Eastern Partnership Summit in Riga the beginning of the end of the policy? The paper does not attempt a comprehensive discussion of the issue, but constitutes an outline of particular problems which the EU and Eastern Partnership are faced with.

\section{THE INFLUENCE OF 2014-2015 EVENTS ON THE SITUATION \\ OF THE EUROPEAN UNION}

Events taking place within the EU, as well as in its international environment (especially those from 2014-2015 period), exert influence upon the Community's policy towards its neighbours. The crisis in the Eurozone, the possibility of Brexit (the UK leaving the EU) as well as war in Syria, the problem of excessive number of immigrants in the Mediterranean region, the issue of Islamic State, annexation of Crimea and Russia's support for separatists in southern and eastern Ukraine, etc. are all worth mentioning while discussing the events. All these lead to the EU member states becoming divided according to a geographical mechanism into 1) those interested in the situation in the Mediterranean area (southern countries, target countries for the masses of immigrants i.e. Germany, Austria, etc.) and 2) countries interested in the situation in the eastern neighbourhood (Poland, Central Europe, the Baltic states, Sweden) where Russia-Ukraine war poses challenges for security of these states and the region.

In addition, the EU's internal problems outlined above, apply to the EU as a whole as well. They pertain to the essence of the EU itself, the European project, its objectives and challenges the Community may face in the future. As Ivan Krastev rightly stated "part of the problem that we have today is that we take the European Union for granted. The more we do this, the higher the risk of its disintegration. The belief that something cannot collapse leads to high-risk behaviour" [Krastev 2015: 8].

Moreover, as far as the collective approach towards problematic issues is concerned, Europe has always been divided. Therefore, the division among the EU 
member states concerning Russia is not surprising. The sanctions constitute a mere exception from the rule. The present division regarding the situation in Ukraine and reaction towards Russia is somewhat different than it was before. Up to the present, the dividing line ran along the East-West of the EU. Currently, the line divides the EU into the North and South. Countries of the North, including the Baltic states and the majority of Central and Eastern Europe perceive Russia as a threat. However, these countries face a difficult issue of devising measures to counter the threat. The UK, for example, views Russia's threat in a different way than e.g. Poland or Sweden does. Countries of the South, on the other hand, are faced with the threat originating from North Africa and the Middle East [Dempsey 2015: 20]. What is more, war in Syria, and the migration crisis caused by it, exert a negative influence on the situation of southern EU member states. In addition, the situation is further complicated by the present Russian air-strikes campaign against targets in Syria, which supports Bashar al-Assad's regime. The air-strikes result in further casualties among civilians and foster immigration to Europe.

The fact that, from Russia's perspective, the weaker the EU, the better the situation for Russia, is worth remembering. Therefore, Judy Dempsey's statement is worth recalling at this point: "a strong Europe means having a coherent and united foreign, security and defence policy. Europe lacks these three essential elements that would make Europe think and act strategically. Without them, Europe is weak" [Dempsey 2015: 23].

\section{RUSSIAN NEO-REVISIONISM IN INTERNATIONAL POLITICS}

Understanding the roots of the Ukrainian crisis without considering the evolution of Russia's foreign policy and its perception of international relations in the near past is difficult. According to Richard Sakwa, Russia's policy in recent years has evolved in the direction of "a 'neo-revisionist' power, setting the stage for the confrontation over Ukraine" [Sakwa 2015: 30]. Sakwa states that Russia's policy change was motivated by at least four issues: "First, the gradual deterioration of the relationship with the EU (...) The second key issue was the gradual breakdown of an inclusive pan-European security system in which Russia could act as an autonomous yet cooperative partner (...). Third, Russia and a number of other 'rising powers', notably China, have challenged American claims to 'exceptionalism' and global leadership. (...) the fourth catalyst for Russian neo-revisionism. This is the ideology of 'democratism', which is distinct from the practices of democracy itself, instead assuming that if democracy is the best possible form of government and the one that is liable to make allies of the states concerned, then all practicable measures should be employed to achieve the desire end. The perception that the West was using democracy promotion as a cover to advance its strategic objectives, including regime change, aroused a host of defensive reactions in Russia" [Sakwa 2015: 31-34]. 
According to Sakwa, neo-revisionism does not denote the attempt at complete annihilation of the existing international order but rather the emphasis on the fact that all powers will follow international rules and regulations and respect Russia's "equivalent" position in the system [Sakwa 2015: 34]. On the other hand, Lilia Shevtsova states that Russia's anti-Western policy originates from several external factors. 1) the West's naivety (providing help for Boris Yeltsin was considered as input into Russia's democratisation), 2) cooperation with Russia over western values (the fact that liberal democracies are no longer a role-model for Russia is one of the woeful phenomena of the last 20 years), 3) Russia did not exploit its defeat in the Cold War in the transition into a state under the rule of law [Szewcowa 2015]. Therefore, Carl Bildt is right in stating that in the recent years Russia has shifted from being the "strategic partner" of the West into its "strategic problem" [Bildt 2015].

GEOPOLITICAL CHANGES IN CENTRAL AND EASTERN EUROPE AFTER 2004 AND 2007

In 2004 and 2007, the European Union was enlarged by the entry of the states from Central and Eastern Europe. Due to the enlargement, the European Union's eastern border was rearranged, causing a change in the geopolitical system of forces in that part of the continent. When Ukraine, Belarus, and Moldova became the immediate neighbours of the Community, the European Union's border with Russia was substantially broadened. The biggest problem connected with the Eastern Partnership is the lack of clear declaration that the countries included in the programme will be accepted into the EU as member states, even if they meet the EU's conditions. It must be pointed out that some of the countries included in the project, as for example Ukraine, openly declare such willingness. The lack of the EU's promise of these countries' membership is yet another evidence that the EU still treats sceptically the issue of the Eastern neighbours membership and that it approaches the relations with these countries in "the shadow of Russia".

\section{EASTERN DIMENSION OF THE EUROPEAN UNION - GENERAL REMARKS}

The Eastern dimension of the EU is directed at the EU's neighbours to the immediate East. More and more frequently, as a result of the Eastern Partnership, countries of the South Caucasus are incorporated into the dimension. However, it does not change the fact that the dimension constitutes an integral element of the EU's external policy. The dimension is also qualitatively different from the Mediterranean and Southern dimensions and may be regarded as a component of the EU's Common Foreign and Security Policy [Kapuśniak 2010]. As far as the dimension's structure is concerned, it is based on two approaches: regional approach - in relation to the whole area of Eastern Europe and bilateral approach - an individual approach 
towards each country of the region [Kapuśniak 2010]. The fact that the EU's latest regional projects result in ambiguities in relations between the ENP and new initiatives directed at the eastern partners: the Black Sea Synergy and the Eastern Partnership, is noteworthy. Should these projects be considered complimentary to the ENP, or do they constitute a competition? Moreover, the question of rivalry for financial resources among various EU dimensions arises. Without these resources the implementation of a successful policy towards the neighbours is impossible. However, it does not change the fact that the ENP contributed to the intensification of the EU-Eastern European states cooperation.

\section{EASTERN PARTNERSHIP OF THE EUROPEAN UNION - FROM THE PRAGUE TO RIGA SUMMIT}

In 2008, during the EU forum, Poland and Sweden submitted a new initiative of the Eastern Partnership (abbrev. EaP), which was accepted as an EU-wise project during Prague Summit (7 May 2009). The EaP was viewed as a supplement to the European Neighbourhood Policy of the EU. The ENP was formalised on 12 May 2004 [Communication from the Commission 2004] by intensification of relations with Eastern European countries: Belarus, Moldova, Ukraine and countries of the South Caucasus: Georgia, Armenia and Azerbaijan [Joint Declaration of the Prague Eastern Partnership Summit 2009].

On 29-30 September 2011, in Warsaw, the second EaP Summit was held. Representatives of all EU member states and their eastern partners from Azerbaijan, Armenia, Georgia, Moldova and Ukraine attended. The summit was also attended by representatives of EU institutions: the European Parliament, European Investment Bank and European Bank for Reconstruction and Development. The summit took place during Poland's presidency in the European Council. A successful implementation of the EaP project was to become the key feature of the presidency. Discussions during the summit were dominated by three main issues: finances (the amount of EU resources for the EaP countries), visa regime and the question of Belarus (the subject of internal situation in Belarus after the presidential election of 19 December 2010 and Lukashenka's repressions against Belarusian opposition).

According to Thomas de Waal, the EaP is an ambitious project and constitutes significant progress in relation to previous initiatives concerning the east. However, as proved by the Warsaw Summit, a larger involvement of the EU in its eastern neighbourhood seems considerably complicated [Waal 2011].

Furthermore, during the third EaP Summit, held in Vilnius on 28-29 November 2013, Ukraine was planned to sign the previously negotiated EU accession agreement. However, Viktor Yanukovych, the president of Ukraine at that time, resigned from signing the agreement. On the other hand, Georgia and Moldova signed the accession papers, which also include the Deep and Comprehensive Free Trade Areas 
(abbrev. DCFTAs). As a result of Ukraine's resignation, the situation spiralled out of control (the Euromaidan and its aftermath for Ukraine's political system). The outcome of the decision is tragic for Ukraine: war with Russia (conventional and unconventional warfare - also known as the hybrid war), annexation of Crimea by Russia, destabilisation of south-eastern Ukraine (the so-called separatist republics of Donetsk and Luhansk supported by Russia), dire economic and military situation, etc.

The Eastern Partnership Summit has taken place in Riga on 21-22 May 2015 during the Latvian presidency over the EU Council. The fourth 2015 EaP Summit have presented a critical momentum for the EU in terms of identifying its response policy to the Russo-Ukrainian hybrid war. The crisis has brought about the unprecedented challenges to the security and economic interests of the EU and its member states which should be faced accordingly [see: Stępniewski 2015: 17-27].

Judy Dempsey was right when she said, "if ever there was a chance for European Union leaders to show courage and take risks, it was at the Eastern Partnership (EaP) summit that took place in Riga on May 21-22" [Dempsey 2015]. Unfortunately, EU policy makers have not decided to make resolute declarations addressed to the $\mathrm{EaP}$ member states. They claimed in their final declaration that the EaP aims "at building a common area of shared democracy, prosperity, stability and increased cooperation and is not directed against anyone" [Joint Declaration of the Eastern Partnership Summit 2015]. EU's poor approach towards Eastern European partners and way of defining the eastern policy regarding Russia were also indicated by Thomas de Waal and Richard Youngs who said that "the EU's policies since 2013 have been framed primarily in terms of how to respond directly to Russia" [Waal, Youngs 2015].

The recent EaP in Riga is criticised much in The American Interest by Andrew Michta who believes that "the EU has no desire to offer any meaningful prospects of membership to the six partners (though only three, Moldova, Ukraine and Georgia, are really in play). Without this overarching inducement, the Eastern Partnership will soon degenerate into another exercise in bureaucratic futility". Also, he argues that in the long run "Europe's timidity in Riga and its unwillingness to offer Eastern Partnership countries a clear path to membership will be revealed as a major geostrategic mistake" [Michta 2015].

\section{THE EASTERN PARTNERSHIP'S PROBLEMS - CLOSING REMARKS}

At this point, some issues which influence the EU's policy towards the East ought to be addressed. In addition, reasons for the ENP and EaP's ineffectiveness ought to be established.

The European Neighbourhood Policy is not an effective policy and faces numerous barriers ensuing from its structural inconsistencies [see: Gromadzki 2008; Balcer, Revak 2012: 59-63]. First of all, the ENP encompasses a group of several dozen countries, from Morocco to Georgia, which manifest different potential and 
aspirations. Some will possibly be accessed to the Community, be it in a distant time perspective, others do not perceive the free trade zone as their ultimate aspiration. As a consequence, the addressees themselves, both eastern and southern ones, feel unappreciated by the EU. Their discontent is further boosted by the fact that the European Economic Area countries - Iceland, Lichtenstein and Norway, were not included in the group, but are still presented with the opportunity of joining the EU, should they express a wish to do so. In addition, countries awaiting candidate status, e.g. Turkey and Western Balkans states, were not included in the group either. On the other hand, the most significant partner of the Community, Russia, was not encompassed, of its own accord, by the neighbourhood programme. In accordance with resolutions of the EU-Russia summit of 2003, the policy of strategic partnership, which is based on four common areas, was embraced [EU-Russia Common Spacer Progress Report 2007].

The effectiveness of the EU's eastern policy depends on the EU itself as well. EU decision-makers perceive the eastern neighbours in a technocratic manner and they are insensitive towards the addressees of the Community's initiatives. History has proved that the perspective of integration was the greatest guarantee of successful internal changes in the applicant countries. Unfortunately, the EU is unable to ensure the membership for countries of the eastern neighbourhood, even in the long-term perspective. The Riga Summit of May 2015 acknowledged the inability. Moreover, the EU is perceived in a negative light by eastern decision-makers and citizens due to the visa regime, which resulted in the emergence of a "glass curtain" on the eastern borders of the Community. The EU ought to undertake actions in order to improve its attractiveness in the eyes of eastern societies. Larger financial aid, prevention of crises by means of introducing preventive measures (more effective economic policies, stabilising missions to regions of conflict, etc.) may serve as example mechanisms of achieving it. The effectiveness of the policy towards the region depends largely on the change in the EU's policy towards Eastern Europe and the South Caucasus [see: Stępniewski 2015: 17-27].

On the one hand, the EU becomes involved in projects such as the European Neighbourhood Policy and the Eastern Partnership, which is based on the ENP. Unfortunately, these projects do not result in a qualitative change of relations between the EU and its eastern partners. On the other hand, the Russian Federation attempts to hold these partners in its own area of influence, which poses difficulties for these countries to break free. The EU's involvement in the East will largely influence the effectiveness of the eastern policy as well as the shape of Eastern European states' political systems and the balance of power in this region of Europe. The question of these countries' direction of foreign policies remains open: will it be the European or eastern direction? As a consequence, much depends on Eastern European countries, but even more lies in the hands of EU decision-makers and their approach towards the eastern neighbours. Unfortunately, regress of democratic reforms in Eastern European countries reflects negatively upon the region and diminishes the EU deci- 
sion-makers' interest in it. The fact that new EU member states will not allow their eastern borders to become the area of poverty, social unrest and instability, a "grey area of security", is noteworthy [see: Stępniewski 2011: 295-320]. These countries, especially Poland and Central European states, which found a safe haven in the EU, ought to support countries of Eastern Europe and contribute to the development of tangible changes in the system, economic transformations and emergence of civil society. The necessity of transformations of Eastern European states, especially Ukraine, is in their interest and the interest of the whole EU as well. On the other hand, the establishment of the Union for the Mediterranean - the integration of southern EU states with neighbours included in the Barcelona Process and the southern dimension of the ENP, poses a threat to the development of the eastern dimension of the EU. As a consequence of the Arab Spring, the southern neighbours have become a greater threat (a competition) for the eastern neighbours as far as EU financial resources and aid are concerned. Seeing the scale of problems arising in the southern neighbourhood, EU decision-makers are far more willing to increase financial aid and boost EU involvement in that region. The eastern neighbourhood is perceived by them as stable and predictable. On the other hand, Russia interprets the ENP and its implementation in the current form as a proof that no further EU enlargement to the east will take place in the coming years. Therefore, Russia will be able to re-establish its influence on the western and southern verges of the post-Soviet space [Stępniewski 2011: 77-118].

Vít Dostál aptly states: "without a doubt, there is a need for change in the EU's neighbourhood policy and especially in its eastern dimension. It might be possible to amend the EaP as an instrument; to channel funds into new areas or to devote more attention to the work on the ground with civil society. However, the EaP needs to be approached as a policy, not as a tool" [Dostál 2015: 110-111].

\section{BIBLIOGRAPHY}

Balcer, A., Revak, L. 2012. Ukraine: European Australia or Congo?, "New Eastern Europe”, no. 2(III)/ April-June, pp. 59-63.

Bildt, C. 2015. Russia, the European Union and the Eastern Partnership, "ECFR Riga Series", http://www. ecfr.eu/wider/rigapapers, 5 July 2015 (access 28.05.2015).

Communication from the Commission: European Neighbourhood Policy - Strategy Paper, COM (2004) 373 final, Brussels, 12 May 2004.

Dempsey, J. 2015. Doubletake: Does Russia Divide Europe?", “New Eastern Europe”, no. 5 (XVIII), September-October, p. 20.

Dempsey, J. 2015. The EU's Blindness About Eastern Europe, "Carnegie Europe: Judy Dempsey's Strategic Europe", 28 May, http://carnegieeurope.eu/strategiceurope/?fa=60229 (access 28.05.2015).

Dostál, V. 2015. Searching for a New Narrative, "New Eastern Europe", no. 5 (XVIII), September-October, pp. 110-111.

EU-Russia Common Spacer Progress Report 2007, http://ec.europa.eu/external_relations/russia/docs/ commonspaces_prog_report2007.pdf. 
Gromadzki, G. 2008. Five Theses on European Neighbourhood Policy, "Batory Foundation Policy Brief", Warsaw, September.

Joint Declaration of the Eastern Partnership Summit (Riga, 21-22 May 2015), European Council, 21-22 May 2015, http://www.consilium.europa.eu/en/meetings/international-summit/2015/05/21-22/ (access 30.06.2015).

Joint Declaration of the Prague Eastern Partnership Summit, Council of the European Union, Prague, 7 May 2009, 8435/09 (Presse 78), http://www.consilium.europa.eu/uedocs/cms_data/docs/pressdata/ en/er/107589.pdf.

Kapuśniak, T. 2010. Wymiar Wschodni Europejskiej Polityki Sąiedztwa Unii Europejskiej. Inkluzja bez czlonkostwa? / The eastern dimension of the European Union's Neighbourhood Policy. Inclusion without membership?, "Zeszyty natolińskie", no. 42, Centrum Europejskie Natolin, Warszawa, http:// www.natolin.edu.pl/pdf/zeszyty/Natolin_Zeszty_42.pdf.

Krastev, I. 2015. How to Avoid Europe's Disintegration, "New Eastern Europe", no. 5 (XVIII), September-October, p. 8.

Michta, A. A. 2015. After the Summit, “The American Interest”, 25 May, http://www.the-american-interest. com/2015/05/25/after-the-summit/ (access 15.06.2015).

Sakwa, R. 2015. Frontline Ukraine: Crisis in the Borderlands, London-New York, p. 30.

Stępniewski, T. 2011. Geopolityka regionu Morza Czarnego w pozimnowojennym świecie, Lublin-Warszawa, pp. 295-320.

Stępniewski, T. 2015. The EU's Eastern Partnership and the Way Forward After Riga, "International Issues \& Slovak Foreign Policy Affairs", vol. XXIV, no. 1-2, pp. 17-27.

Szewcowa, L. 2015. Polem gry Kremla jest chaos, trans. by Andrzej Ehrlich, "Gazeta Wyborcza / Magazyn Świąteczny”, 27 June, http://wyborcza.pl/magazyn/1,145325,18248326,Polem_gry_Kremla_jest_chaos.html\#TRwknd (access 27.06.2015).

Waal, T. de. 2011. Expanding the EU's Ostpolitik, "Strategic Europe", 24 October, http://carnegieeurope. eu/publications/?fa=45792 (access 15.06.2015).

Waal, T. de, Youngs, R. 2015. Reform as Resilience: An Agenda for the Eastern Partnership, Carnegie Endowment for International Peace, 14 May, http://carnegieendowment.org (access 17.06.2015).

\section{BIOGRAPHY}

Tomasz Stępniewski, Doctor habilitatus (the Polish Academy of Science, Warsaw, Poland). Associate professor at the Institute of Political Science, Faculty of Social Sciences, The John Paul II Catholic University of Lublin and Institute of East-Central Europe (IESW), Lublin. His research interests include the European Union's eastern policy, international relations of the Commonwealth of the Independent States' area, Russia’s policy towards Eastern Europe. E-mail: tomasz.stepniewski5@gmail.com 